\title{
VALINIA INIA, A NEW EARLY STORAGE ONION VARIETY FOR CENTRAL SOUTH CHILE
}

\author{
María Inés González A. ${ }^{*}$, and Patricia Herrera V. ${ }^{1}$
}

In Central South Chile, storage onion varieties (Allium cepa L.) sold domestically usually begin the maturation process in March, which implies that a large proportion of bulbs do not mature adequately and do not resist prolonged storage. This situation led the Quilamapu vegetable program of the Instituto de Investigaciones Agropecuarias INIA to select an early maturing onion variety. This breeding method involved a recurrent selection with free plant crossing that began in 1994 on a population of 2000 plants of the 'Valenciana' commercial variety. Plants were first selected when they reached physiological maturity (tops down before 28 February), and then for shape, size, storage capacity, and single-centered bulbs. The result of the program was 'Valinia INIA', a type of Valenciana onion variety: early maturing, medium-sized bulb, spherical, yellow, and resistant to sprouting during storage. From the 2001-2002 to the 2008-2009 season, variety assays were carried out to compare 'Valinia INIA' with commercial cultivars, i.e., 'Sintética 14', 'Grano de Oro', and 'Valenciana Cobra'. 'Valinia INIA' precocity exceeded the other varieties in all seasons with a mean of 1.5 wk ahead of 'Sintética 14', which is the earliest commercial variety and more than $2 \mathrm{wk}$ ahead of the other two. Its yield is similar to 'Valenciana Cobra' and higher than the other two varieties. Its storage capacity is similar to 'Grano de Oro' and 'Sintética 14', but greater than 'Valenciana Cobra'.

Key words: Allium cepa, cultivar, precocity, storage capacity, single center.

$\mathrm{I}$ $\mathrm{n}$ the irrigated valley of Central South Chile, storage onion varieties (Allium cepa L.) usually begin the maturation process in March. This implies that a large proportion of bulbs fail to mature properly, thus affecting their storage capacity resulting in early sprouting and/ or rot. It is known that the presence of a high percentage of immature bulbs or thick-necked onions is related to latitude, planting season, and late storage cultivars (Brewster et al., 1987).

The onion is a cross-pollination plant since it exhibits protandry (Brewster, 2008). Furthermore, it is a biennial plant that produces a bulb in the first year and scapes with its seeds in the second year, allowing the selection of desirable characteristics in the first year. The selected bulbs are planted in the second year after storage to obtain seeds.

According to Havey (2000), due to new technologies available today, many onion breeders have underestimated the power of recurrent phenotypic selection. Moreover, he reports data on the increase of the onion bulb's soluble solid content from 14 to $21 \%$ in three generations of mass selection. Mass selection was amply used in Europe to develop open pollination onion varieties up to the 80 s

${ }^{1}$ Instituto de Investigaciones Agropecuarias INIA, Casilla 426, Chillán, Chile. *Corresponding author (mgonzale@inia.cl).

Received: 30 June 2011.

Accepted: 20 December 2011.
(Brewster, 2008). In Argentina's Instituto Nacional de Tecnología Agropecuaria (INTA) onion breeding program, recurrent selection is used in populations of the Valenciana type, and its objectives are precocity and good storage capacity. Thus, after $12 \mathrm{yr}$ of selection, they have achieved varieties with the desired characteristics, as in the case of 'Cobriza INTA', an onion with excellent storage capacity and darker cataphylls (Galmarini, 2000; Galmarini et al., 2001). There are other reports on the effectiveness of selection on characteristics such as precocity and storage capacity of onions (McCallum et al., 2001; Cardoso and da Costa, 2003). On the other hand, when comparing open-pollinated (OP) onion varieties with hybrid varieties, no consistent superiority of the latter has been found in both yield and bulb quality (Cramer, 2001).

The objective of the Quilamapu Vegetable Breeding Program of the Instituto de Investigaciones Agropecuarias INIA was to select an early storage onion variety that could reach maturity during February in Central South Chile and maintain yield and quality characteristics of the Valenciana type commercial onion cultivars.

\section{MATERIALS AND METHODS}

The applied breeding method was recurrent selection with cross-pollination of the plant population, which began with a population of 2000 plants of the Valenciana 
commercial variety with open pollination and established with seedling transplants in October 1994 in the Quilamapu INIA Santa Rosa Experimental Station $\left(36^{\circ} 32^{\prime} \mathrm{S} ; 7^{\circ} 55^{\prime} \mathrm{W}\right)$ in a volcanic soil classified as Tipic Dystrandepts. The climate is typical Mediterranean with a mean annual precipitation of $1200 \mathrm{~mm}$ and a mean annual temperature of $13.1{ }^{\circ} \mathrm{C}$, minimum of $3.0^{\circ} \mathrm{C}$ in July and maximum of $28.6^{\circ} \mathrm{C}$ in January (del Pozo and del Canto, 1999).

Plants were first selected when they reached physiological maturity (tops down before 28 February). After this selection for precocity and subsequent to the curing process, bulbs were selected for size (diameter $>$ $7 \mathrm{~cm}$ ), shape (spherical), and then stored in warehouses. During storage, all sprouted and soft bulbs were discarded and the rest were planted in the next season for seed production. Since this is a permanent selection process, it is repeated each season. However, when $100 \%$ of the plant population reached physiological maturity before 28 February, variety trials started to compare 'Valinia INIA' with other commercial cultivars.

The top third of the bulbs planted for seed production was cut to stimulate sprouting and select those that were single-centered, which is a characteristic required by agribusiness to produce onion rings. Starting in the 20012002 season, single-centered bulbs were planted and the percentage of total stored bulbs with this characteristic was registered.

In August of every season, the selected bulbs were planted in rows spaced $80 \mathrm{~cm}$ apart and with $30 \mathrm{~cm}$ between bulbs. The umbels were cut along with $10 \mathrm{~cm}$ of scape during February when they showed ripe seeds due to capsule dehiscence. The umbels were dried after harvest.

From the 2001-2002 to the 2008-2009 season, six variety assays were carried out at the INIA Quilamapu Santa Rosa Experimental Station in the Bío Bío Region and two others at the INIA Raihuén Experimental Station (35'42' $\mathrm{S} ; 71^{\circ} 40^{\prime} \mathrm{W}$ ) in the Maule Region in order to compare 'Valinia INIA' with the 'Sintética 14' (ANASAC), 'Grano de Oro' (Seminis), and 'Valenciana Cobra' (ANASAC) commercial cultivars. Seedlings were established in double rows of plants spaced $10 \mathrm{~cm}$ apart on ridges spaced $50 \mathrm{~cm}$ apart and reached a population equivalent to 400000 plants $\mathrm{ha}^{-1}$. Variety assays were planted between 6 and 19 October of each year.

A randomized complete block design was used for these assays along with four replicates and a $2 \times 7 \mathrm{~m}$ plot.

\section{Evaluations}

For each season and location, variety precocity was evaluated by marking the plants that reached physiological maturity before 28 February. Commercial yield was determined at harvest and bulbs with flower stems, those with a diameter less than $5 \mathrm{~cm}$, and thick-necked onions, which were culls. Furthermore, the percentage of spherical bulbs and those with a diameter greater than 7 $\mathrm{cm}$ were determined.

Storage capacity of bulbs harvested in the 2008-2009 season in the Bío Bío Region was evaluated in the last season. In order to evaluate storage capacity, 100 mature and healthy bulbs with a diameter greater than $7 \mathrm{~cm}$ were randomly chosen from each replicate in February, placed in mesh bags and taken to a warehouse where the number of sprouted and/or soft bulbs were counted weekly and removed from the mesh bags.

An ANOVA was carried out on the results of all the variety assays with the IRRISTAT (IRRI, 2003) statistical program and means were compared by the LSD test $(\mathrm{P} \leq$ $0.05)$.

\section{RESULTS AND DISCUSSION}

\section{Selection of 'Valinia INIA'}

From the start (February 1995), there were records of the percentage of plants that matured in February; an important gain in this characteristic resulted in yearly increases from $21 \%$ in February 1995 to $100 \%$ in the last seasons (Table 1).

Although beginning with the February 1995 harvest, spherical bulbs with a diameter greater than $7 \mathrm{~cm}$ were selected for storage and seed production in the following season, there are records of the percentage of bulbs with these characteristics only since the 1998-1999 season (Table 1). It can be generally observed that there has been no significant variation of these characteristics over time, except for the 2004-2005 in which bulb size significantly decreased (Table 1). In that season, the yield of all onion varieties was affected (Table 2) due to a severe mildew (Peronospora destructor) attack and a high weed population. In a study of genetic variability in onion (Buzar et al., 2007), 58\% of the variability was determined by the following descriptors: total sugar content, bulb length, number of days from planting to harvest, percentage of bulbs with an equatorial diameter between 70 and $90 \mathrm{~mm}$, and bulb mean weight.

Table 1. Variation over time of the selected characteristics in 'Valinia INIA' at harvest. All percentages are calculated based on the number of bulbs.

\begin{tabular}{lcccc}
\hline Season & $\begin{array}{c}\text { Percentage } \\
\text { of tops } \\
\text { down in } \\
\text { February }\end{array}$ & $\begin{array}{c}\text { Spherical } \\
\text { bulbs } \\
\text { \% early } \\
\text { plants) }\end{array}$ & $\begin{array}{c}\text { Bulbs with } \\
\text { diameter } \\
>7 \text { cm }(\% \\
\text { spherical) }\end{array}$ & $\begin{array}{c}\text { Single- } \\
\text { centered } \\
\text { bulbs }(\% \\
\text { stored bulbs) }\end{array}$ \\
\hline $1994-1995$ & 21 & - & - & - \\
$1996-1997$ & 10 & - & - & - \\
$1998-1999$ & 81 & 63 & - & - \\
$2001-2002$ & 100 & 75 & 91 & - \\
$2002-2003$ & 79 & 68 & 89 & 23 \\
$2003-2004$ & 83 & 87 & 86 & 90 \\
$2004-2005$ & 100 & 77 & 31 & 78 \\
$2005-2006$ & 77 & 63 & 61 & 65 \\
$2006-2007$ & 80 & 85 & 61 & 78 \\
$2007-2008$ & 100 & 61 & 76 & 70 \\
$2008-2009$ & 100 & 80 & 55 & 82 \\
$2009-2010$ & 100 & 50 & 92 & 82 \\
$2010-2011$ & 100 & 69 & 72 & 90 \\
\hline
\end{tabular}


Table 2. Marketable bulb yield of 'Valinia INIA' compared to commercial onion varieties at the INIA Quilamapu (Bío Bío Region) and INIA Raihuén (Maule Region) Experimental Stations.

\begin{tabular}{lccccr}
\hline Season & $\begin{array}{c}\text { Valinia } \\
\text { INIA }\end{array}$ & $\begin{array}{c}\text { Valenciana } \\
\text { Cobra }\end{array}$ & $\begin{array}{c}\text { Grano } \\
\text { de Oro }\end{array}$ & $\begin{array}{c}\text { Sintética } \\
14\end{array}$ & $\begin{array}{r}\text { CV } \\
(\%)\end{array}$ \\
\cline { 2 - 6 } Quilamapu & & \multicolumn{5}{c}{ t ha $^{-1}$ } & & \\
$2001-2002$ & $92.6 \mathrm{a}$ & $81.4 \mathrm{ab}$ & $91.5 \mathrm{a}$ & $61.4 \mathrm{~b}$ & 22.2 \\
$2002-2003$ & $76.2 \mathrm{ab}$ & $95.8 \mathrm{a}$ & $55.0 \mathrm{~b}$ & $71.6 \mathrm{ab}$ & 21.0 \\
$2003-2004$ & $73.4 \mathrm{a}$ & $63.1 \mathrm{a}$ & $74.3 \mathrm{a}$ & $68.6 \mathrm{a}$ & 15.7 \\
$2004-2005$ & $55.4 \mathrm{a}$ & $51.4 \mathrm{a}$ & $48.5 \mathrm{a}$ & $41.8 \mathrm{a}$ & 21.4 \\
$2007-2008$ & $84.1 \mathrm{a}$ & $83.7 \mathrm{a}$ & $78.7 \mathrm{a}$ & $70.1 \mathrm{~b}$ & 6.2 \\
$2008-2009$ & $60.5 \mathrm{~b}$ & $69.4 \mathrm{a}$ & $69.8 \mathrm{a}$ & $50.0 \mathrm{c}$ & 8.4 \\
Raihuén & & & & & \\
$2007-2008$ & $119.1 \mathrm{a}$ & $112.4 \mathrm{ab}$ & $99.8 \mathrm{~b}$ & $77.2 \mathrm{c}$ & 8.8 \\
$2008-2009$ & $124.3 \mathrm{a}$ & $124.4 \mathrm{a}$ & $110.8 \mathrm{a}$ & $73.7 \mathrm{~b}$ & 16.2 \\
Mean & 85.7 & 85.2 & 78.6 & 64.3 & \\
\hline
\end{tabular}

Means followed by different letters in the rows are significantly different $(\mathrm{P} \leq 0.05)$ according to LSD test; CV: coefficient of variation.

With regard to selecting single-centered bulbs (Figure 1 ), there has also been a gain of up to $90 \%$ of the total stored bulbs, but there are variations from year to year (Table 1). Single-centeredness is a low heritability trait, highly influenced by plant vigor, and this characteristic was closely related to bulb size in this study; in general, the biggest bulbs tended to produce multiple centers. It has been observed in onion variety assays conducted in the United States that this characteristic exhibits great variability in each cultivar from season to season (Shock et al., 2005).

\section{Variety assays}

It was found in these assays that the yield of 'Valinia INIA' did not differ (healthy bulbs with a diameter $>5 \mathrm{~cm}$ ) from the commercial varieties and was even higher than 'Sintética 14' (Table 2). Yield, which is a characteristic greatly influenced by crop conditions, depends directly on bulb size and weight. The objectives of these onion breeding programs do not generally include only increasing yield, but rather bulb quality characteristics, precocity, and resistance to disease. In fact, the Valenciana type storage var. Cobriza INTA (INTA Argentina) does not have a higher yield than

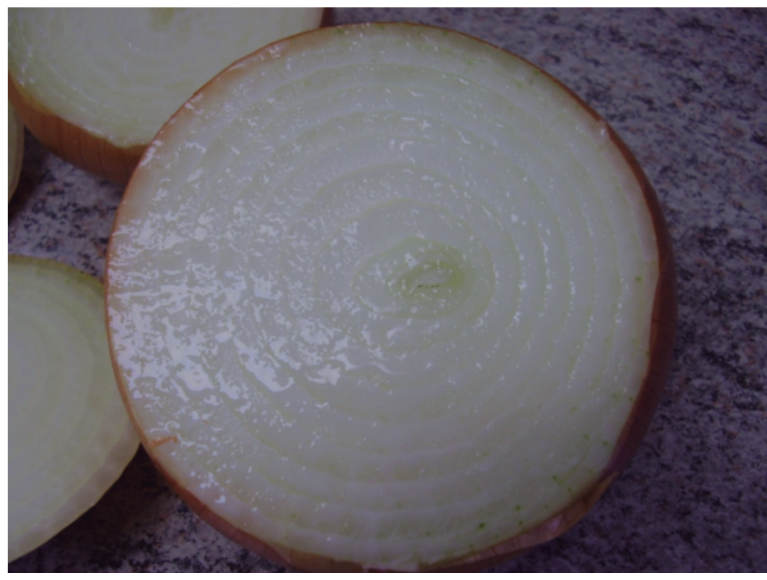

Figure 1. 'Valinia INIA' single-centered onion bulb. the most widely used variety in that country, 'Valcatorce INTA' (Galmarini et al., 2001), which corresponds to the Chilean variety Sintética 14 (González, 1997).

When evaluating precocity, 'Valinia INIA' has a clear advantage with regard to the other commercial varieties with a mean of $1.5 \mathrm{wk}$ ahead of 'Sintética 14', which is the earliest commercial variety and more than $2 \mathrm{wk}$ ahead of the other two varieties $(\mathrm{P} \leq 0.05)$ (Table 3$)$. The assay was repeated in the 2008-2009 season in both Quilamapu and Raihuén where it was found that the precocity of 'Valinia INIA' is also evident in the Maule Region (Table 4). Another precocity indicator is the absence of thicknecked onions, immature bulbs not in dormancy, which occur when the plant has not reached maturity when the temperature begins to fall and the photoperiod shortens and leads to a reversal of the maturation process of the bulb to vegetative growth (Brewster, 2008). This occurs in Central South Chile when the bulb maturation process is not yet complete in March. It is known that the time required for bulb maturity decreases linearly with increasing temperature and lengthening photoperiod (Khokhar, 2008). 'Valinia INIA' had very few thicknecked onions in the six seasons evaluated in the Bío Bío Region (Table 5). In the assays conducted in Raihuén (Maule Region), none of the varieties produced thicknecked onions in the two seasons.

Table 3. Percentage of 'Valinia INIA' plants that reached physiological maturity in February compared with commercial onion varieties during four seasons in the INIA Quilamapu (Bío Bío Region) Experimental Station.

\begin{tabular}{lccccc}
\hline Season & $\begin{array}{c}\text { Valinia } \\
\text { INIA }\end{array}$ & $\begin{array}{c}\text { Valenciana } \\
\text { Cobra }\end{array}$ & $\begin{array}{c}\text { Grano } \\
\text { de Oro }\end{array}$ & $\begin{array}{c}\text { Sintética } \\
14\end{array}$ & $\begin{array}{c}\text { CV } \\
(\%)\end{array}$ \\
\hline $2001-2002$ & $100 \mathrm{a}$ & $95 \mathrm{~b}$ & $96 \mathrm{~b}$ & $100 \mathrm{a}$ & 1.5 \\
$2002-2003^{1}$ & 100 & 50 & 50 & 55 & \\
$2003-2004$ & $85 \mathrm{a}$ & $28 \mathrm{c}$ & $28 \mathrm{c}$ & $43 \mathrm{~b}$ & 14.6 \\
$2004-2005$ & $100 \mathrm{a}$ & $16 \mathrm{~b}$ & $11 \mathrm{~b}$ & $13 \mathrm{~b}$ & 11.2 \\
Mean & 96.3 & 47.3 & 46.3 & 52.8 &
\end{tabular}

Means followed by different letters in the rows are significantly different $(\mathrm{P} \leq 0.05)$ according to DMS test.

$\mathrm{CV}$ : coefficient of variation

${ }^{1}$ No statistical analysis was done because maturity data were not separately reported for each replicate.

Table 4. Precocity of onion varieties determined for the percentage of mature bulbs during January and February 2009 in the INIA Quilamapu (Bío Bío Region) and INIA Raihuén (Maule Region) Experimental Stations.

\begin{tabular}{|c|c|c|c|c|}
\hline Date & $\begin{array}{c}\text { Valinia } \\
\text { INIA }\end{array}$ & $\begin{array}{c}\text { Valenciana } \\
\text { Cobra }\end{array}$ & $\begin{array}{l}\text { Grano } \\
\text { de Oro }\end{array}$ & $\begin{array}{c}\text { Sintética } \\
14\end{array}$ \\
\hline \multicolumn{5}{|l|}{ Quilamapu } \\
\hline $13 / 01 / 09$ & $3.9 \mathrm{a}$ & $0.0 \mathrm{~b}$ & $0.0 \mathrm{~b}$ & $0.0 \mathrm{~b}$ \\
\hline $16 / 01 / 09$ & $5.7 \mathrm{a}$ & $0.0 \mathrm{~b}$ & $0.0 \mathrm{~b}$ & $0.0 \mathrm{~b}$ \\
\hline $19 / 01 / 09$ & $10.8 \mathrm{a}$ & $0.0 \mathrm{~b}$ & $0.0 \mathrm{~b}$ & $0.0 \mathrm{~b}$ \\
\hline $22 / 01 / 09$ & $17.9 \mathrm{a}$ & $0.0 \mathrm{~b}$ & $0.0 \mathrm{~b}$ & $0.8 b$ \\
\hline $26 / 01 / 09$ & $66.9 \mathrm{a}$ & $0.4 \mathrm{c}$ & $0.0 \mathrm{c}$ & $17.0 \mathrm{~b}$ \\
\hline $29 / 01 / 09$ & $82.1 \mathrm{a}$ & $0.8 \mathrm{c}$ & $0.4 \mathrm{c}$ & $18.4 \mathrm{~b}$ \\
\hline \multicolumn{5}{|l|}{ Raihuén } \\
\hline $15 / 01 / 09$ & $17.0 \mathrm{a}$ & $0.0 \mathrm{~b}$ & $0.0 \mathrm{~b}$ & $0.0 \mathrm{~b}$ \\
\hline $19 / 01 / 09$ & $39.1 \mathrm{a}$ & $0.0 \mathrm{~b}$ & $0.0 \mathrm{~b}$ & $2.7 b$ \\
\hline $23 / 01 / 09$ & $91.7 \mathrm{a}$ & $3.5 \mathrm{c}$ & $2.4 \mathrm{c}$ & $30.2 b$ \\
\hline $28 / 01 / 09^{1}$ & - & 24.9 & 18.2 & 99.7 \\
\hline $04 / 02 / 09^{1}$ & - & 71.2 & 67.8 & - \\
\hline $07 / 02 / 09^{1}$ & - & 99.3 & 95.3 & - \\
\hline
\end{tabular}

Means followed by different letters in the rows are significantly different $(\mathrm{P} \leq 0.05)$ according to LSD test.

'No statistical analysis was done because 'Valinia INIA' had already been harvested. 
Table 5. Calculation of percentage of thick-necked onions based on the number of bulbs of the varieties evaluated in the INIA Quilamapu (Bío Bío Region) Experimental Station.

\begin{tabular}{lccrcr}
\hline Season & $\begin{array}{c}\text { Valinia } \\
\text { INIA }\end{array}$ & $\begin{array}{c}\text { Valenciana } \\
\text { Cobra }\end{array}$ & $\begin{array}{c}\text { Grano } \\
\text { de Oro }\end{array}$ & $\begin{array}{c}\text { Sintética } \\
14\end{array}$ & $\begin{array}{c}\text { CV } \\
(\%)\end{array}$ \\
\hline $2001-2002$ & $0.0 \mathrm{~b}$ & $4.3 \mathrm{a}$ & $3.4 \mathrm{a}$ & $0.0 \mathrm{~b}$ & 9.4 \\
$2002-2003$ & $0.0 \mathrm{c}$ & $12.6 \mathrm{~b}$ & $35.4 \mathrm{a}$ & $2.8 \mathrm{c}$ & 16.7 \\
$2003-2004$ & $0.0 \mathrm{~b}$ & $12.0 \mathrm{a}$ & $6.9 \mathrm{a}$ & $0.0 \mathrm{~b}$ & 14.0 \\
$2004-2005$ & $2.2 \mathrm{~b}$ & $22.7 \mathrm{a}$ & $27.3 \mathrm{a}$ & $31.5 \mathrm{a}$ & 14.7 \\
$2007-2008$ & $4.7 \mathrm{~b}$ & $13.6 \mathrm{a}$ & $14.0 \mathrm{a}$ & $1.7 \mathrm{~b}$ & 12.5 \\
$2008-2009$ & $4.7 \mathrm{ab}$ & $9.2 \mathrm{a}$ & $9.5 \mathrm{a}$ & $2.4 \mathrm{~b}$ & 17.3 \\
Mean & 1.9 & 12.4 & 16.1 & 6.4 &
\end{tabular}

Means followed by different letters in the rows are significantly different $(\mathrm{P} \leq 0.05)$ according to LSD test. Data were transformed with square root to decrease the coefficient of variation, but original values are shown.

$\mathrm{CV}$ : coefficient of variation.

For bulb characteristics such as shape and diameter that were also selected, 'Valinia INIA' did not differ in general from the commercial varieties and had no loss of quality in these aspects (Tables 6 and 7). However, on the average, 'Valinia INIA' has a higher proportion of spherical bulbs (Table 6, Figure 2).

Bulbs from the Maule and Bío Bío Regions stored since the 2008-2009 harvest season were able to express their potential storage capacity in all varieties with sprouted and/or soft bulbs appearing $150 \mathrm{~d}$ after being stored. However, the total storage period of bulbs harvested in the Maule Region (Raihuén) was shorter for all varieties. 'Valinia INIA' bulbs harvested in the Bío Bío Region

Table 6. Percentage of spherical bulbs in 'Valinia INIA' compared with commercial onion varieties in INIA Quilamapu (Bío Bío Region) and INIA Raihuén (Maule Region) Experimental Stations. Percentages are calculated on the total number of bulbs.

\begin{tabular}{lccccr}
\hline Season & $\begin{array}{c}\text { Valinia } \\
\text { INIA }\end{array}$ & $\begin{array}{c}\text { Valenciana } \\
\text { Cobra }\end{array}$ & $\begin{array}{c}\text { Grano } \\
\text { de Oro }\end{array}$ & $\begin{array}{c}\text { Sintética } \\
14\end{array}$ & $\begin{array}{r}\text { CV } \\
(\%)\end{array}$ \\
\hline Quilamapu & & & & & \\
$2001-2002$ & $75 \mathrm{a}$ & $62 \mathrm{~b}$ & $72 \mathrm{a}$ & $72 \mathrm{a}$ & 7.8 \\
$2002-2003$ & $68 \mathrm{a}$ & $75 \mathrm{a}$ & $46 \mathrm{~b}$ & $77 \mathrm{a}$ & 15.8 \\
$2003-2004$ & $87 \mathrm{a}$ & $78 \mathrm{a}$ & $81 \mathrm{a}$ & $89 \mathrm{a}$ & 7.6 \\
$2004-2005$ & $77 \mathrm{a}$ & $47 \mathrm{~b}$ & $53 \mathrm{~b}$ & $45 \mathrm{~b}$ & 12.1 \\
$2007-2008$ & $79 \mathrm{a}$ & $65 \mathrm{~b}$ & $54 \mathrm{c}$ & $71 \mathrm{~b}$ & 5.6 \\
$2008-2009$ & $85 \mathrm{a}$ & $58 \mathrm{~b}$ & $51 \mathrm{c}$ & $80 \mathrm{a}$ & 4.9 \\
Raihuén & & & & & \\
$2007-2008$ & $77 \mathrm{a}$ & $73 \mathrm{ab}$ & $65 \mathrm{~b}$ & $51 \mathrm{c}$ & 11.0 \\
$2008-2009$ & $79 \mathrm{a}$ & $72 \mathrm{ab}$ & $57 \mathrm{c}$ & $68 \mathrm{~b}$ & 9.0 \\
Mean & 78.4 & 66.3 & 59.8 & 69.1 &
\end{tabular}

Means followed by different letters in the rows are significantly different $(\mathrm{P} \leq 0.05)$ according to LSD test.

$\mathrm{CV}$ : coefficient of variation.

Table 7. Percentage of bulbs with diameter $>7 \mathrm{~cm}$ in 'Valinia INIA' compared with commercial onion varieties in the INIA Quilamapu (Bío Bío Region) and INIA Raihuén (Maule Region) Experimental Stations. Percentages are calculated on the number of commercial bulbs.

\begin{tabular}{lccccr}
\hline Season & $\begin{array}{c}\text { Valinia } \\
\text { INIA }\end{array}$ & $\begin{array}{c}\text { Valenciana } \\
\text { Cobra }\end{array}$ & $\begin{array}{c}\text { Grano } \\
\text { de Oro }\end{array}$ & $\begin{array}{c}\text { Sintética } \\
14\end{array}$ & $\begin{array}{r}\text { CV } \\
(\%)\end{array}$ \\
\hline Quilamapu & & & & & \\
$2001-2002$ & $91 \mathrm{a}$ & $95 \mathrm{a}$ & $91 \mathrm{a}$ & $67 \mathrm{~b}$ & 16.4 \\
$2002-2003$ & $89 \mathrm{a}$ & $98 \mathrm{a}$ & $90 \mathrm{a}$ & $90 \mathrm{a}$ & 6.7 \\
$2003-2004$ & $86 \mathrm{a}$ & $83 \mathrm{a}$ & $85 \mathrm{a}$ & $68 \mathrm{~b}$ & 7.3 \\
$2004-2005$ & $31 \mathrm{a}$ & $41 \mathrm{a}$ & $34 \mathrm{a}$ & $29 \mathrm{a}$ & 37.1 \\
$2007-2008$ & $85 \mathrm{a}$ & $89 \mathrm{a}$ & $84 \mathrm{a}$ & $69 \mathrm{~b}$ & 7.2 \\
$2008-2009$ & $57 \mathrm{~b}$ & $78 \mathrm{a}$ & $72 \mathrm{ab}$ & $27 \mathrm{c}$ & 16.0 \\
Raihuén & & & & & \\
$2007-2008$ & $95 \mathrm{a}$ & $96 \mathrm{a}$ & $98 \mathrm{a}$ & $89 \mathrm{~b}$ & 2.2 \\
$2008-2009$ & $97 \mathrm{a}$ & $95 \mathrm{a}$ & $92 \mathrm{a}$ & $70 \mathrm{~b}$ & 11.4 \\
Mean & 78.9 & 84.4 & 80.8 & 63.6 & \\
\hline
\end{tabular}

Means followed by different letters in the rows are significantly different $(\mathrm{P} \leq 0.05)$ according to LSD test.

$\mathrm{CV}$ : coefficient of variation.

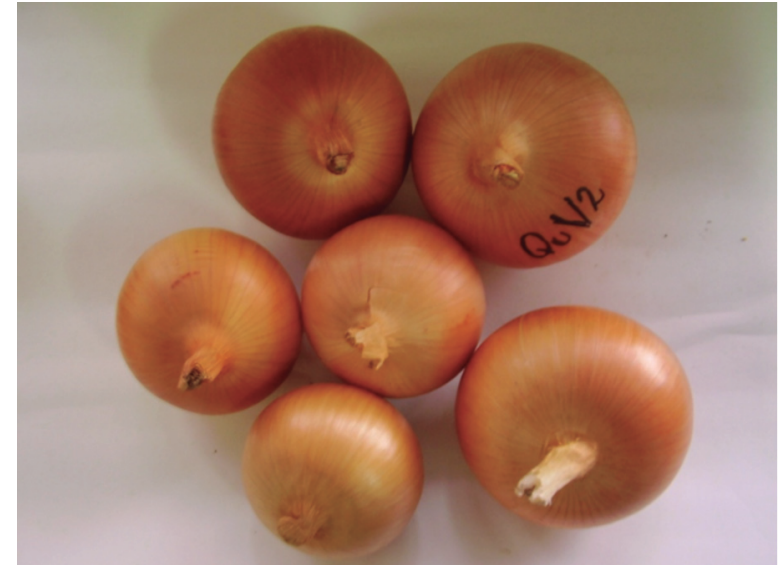

Figure 2. 'Valinia INIA' spherical yellow onion bulbs.

maintained $50 \%$ of bulbs in good conditions up to 320 $\mathrm{d}$ of storage, whereas 'Valenciana Cobra' reached only $215 \mathrm{~d}$ (Figure 3). This characteristic is important since a variety with a storage potential longer than 6 mo prevents the use of sprouting inhibitors, such as maleic hydrazide (Grevsen and Sorensen, 2004). Furthermore, early storage onion cultivars are affected in their storage capacity
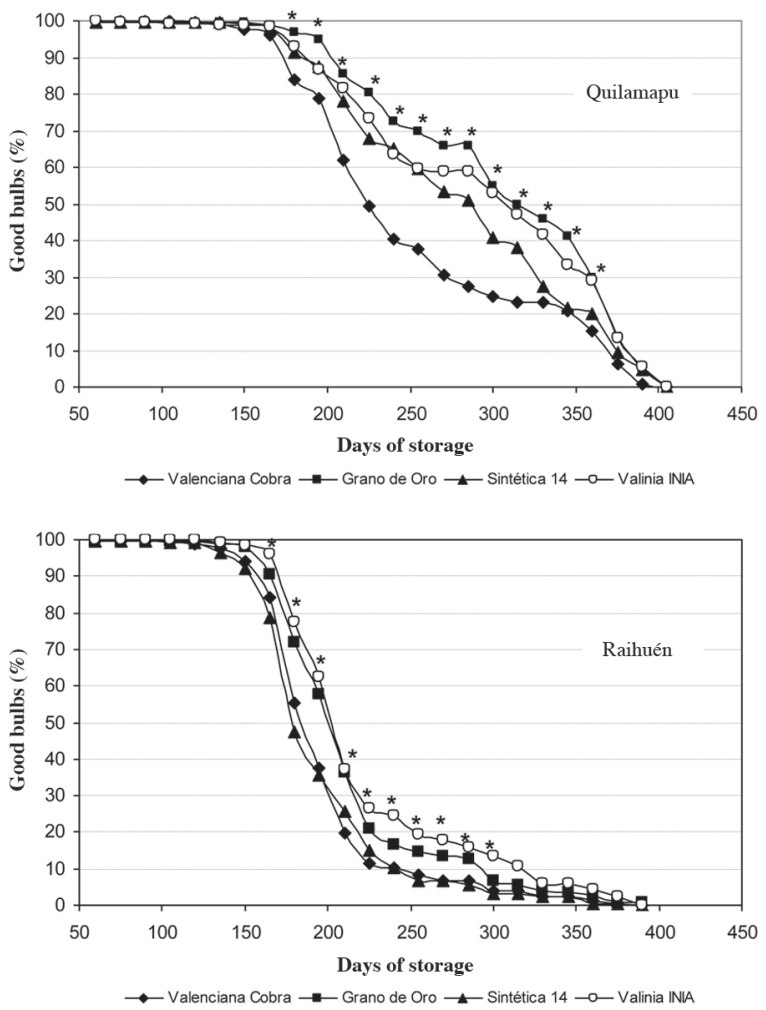

Asterisks indicate significant differences in the measurements among varieties according to the LSD test $(\mathrm{P} \leq 0.05)$.

Figure 3. Evaluation of bulb storage capacity of onion varieties harvested in February 2009 in INIA Quilamapu (Bío Bío Region) and INIA Raihuén (Maule Region) expressed as a percentage of good bulbs (unsprouted and not soft) over time. 
compared with later cultivars (Muro et al., 2006), but this is not observed in 'Valinia INIA'.

\section{CONCLUSIONS}

The Quilamapu Vegetable Breeding Program of INIA obtained and registered (Lista de variedades protegidas, Servicio Agrícola y Ganadero de Chile, Resolución 37/11) 'Valinia INIA' as a Valenciana type storage onion variety: early maturing, medium-sized bulb, spherical, yellow, high percentage of single-centered bulbs, and resistant to sprouting in storage.

Valinia INIA, una nueva variedad de cebolla de guarda precoz para la zona centro sur de Chile. En la zona centro sur de Chile es habitual que las variedades de cebolla (Allium cepa L.) de guarda que se comercializan en el país inicien el proceso de maduración preferentemente en marzo, lo que conlleva a que una gran proporción de bulbos no madure adecuadamente, no resistiendo el almacenaje por un tiempo prolongado. Esta situación llevó al programa de hortalizas del Instituto de Investigaciones Agropecuarias INIA Quilamapu a la selección de una variedad de cebolla de madurez precoz. El método de mejoramiento fue selección recurrente con cruzamiento libre de las plantas, la que se inició el año 1994 sobre una población de 2000 plantas de la variedad comercial Valenciana. Las plantas se seleccionaron, en primera instancia, cuando alcanzaban la madurez fisiológica (doblamiento del cuello de la planta antes del 28 de febrero), y posteriormente por su forma, tamaño, capacidad de guarda y bulbos con centro único. Como resultado del programa se obtuvo 'Valinia INIA', una variedad de cebolla de guarda tipo Valenciana, de maduración temprana, bulbo de tamaño medio, esférico, color dorado y resistente a la brotación en almacenaje. Desde la temporada 2001-2002 hasta la temporada 2008-2009 se hicieron ensayos varietales para comparar 'Valinia INIA' con los cultivares comerciales 'Sintética 14', 'Grano de Oro' y 'Valenciana Cobra'. En todas las temporadas, 'Valinia INIA' superó en precocidad a las demás variedades, adelantándose en promedio 1,5 semanas a 'Sintética 14', que es la variedad comercial más precoz, y más de 2 semanas a las otras dos. En rendimiento fue similar a 'Valenciana Cobra' y superior a las otras dos. Su capacidad de guarda fue similar a 'Grano de Oro' y 'Sintética 14', pero superior a 'Valenciana Cobra'.
Palabras clave: Allium cepa, cultivar, precocidad, capacidad de guarda, centro único.

\section{LITERATURE CITED}

Brewster, J.L. 2008. Onions and other vegetable Alliums. $2^{\text {nd }}$ ed. 411 p. CAB International, Wallingford, UK.

Brewster, J.L., W. Lawes, and A.J. Whitlock. 1987. The phenology of onion bulb development at different sites and its relevance to incomplete bulbing ('thick-necking'). Journal of Horticultural Science 62:371-378

Buzar, A.G.R., V.R. Oliveira, e L.S. Boiteux. 2007. Estimativa da diversidade genética de germoplasma de cebola via descritores morfológicos, agronômicos e bioquímicos. Horticultura Brasileira 25:527-532.

Cardoso, A.I.I., and C.P. da Costa. 2003. Selection for bulb maturity in onion. Scientia Agricola 60:59-63.

Cramer, C.S. 2001. Comparison of open-pollinated and hybrid onion varieties for New Mexico. HortTechnology 11:119-123.

Del Pozo, A., y P. del Canto. 1999. Áreas agroclimáticas y sistemas productivos de la VII y VIII regiones. Serie Quilamapu No 113.115 p. Instituto de Investigaciones Agropecuarias, Centro Regional de Investigación Quilamapu, Chillán, Chile.

Galmarini, C.R. 2000. Onion cultivars released by La Consulta Experiment Station, INTA, Argentina. HortScience 35:13601362.

Galmarini, C.R., P. Della Gaspera, and H. Fuligna. 2001. New Argentine onion cultivars. Acta Horticulturae 555:259-261.

González, M.I. 1997. Effect of sowing date on the production of three storage varieties of onion in the Eighth Region of Chile. Acta Horticulturae 433:549-554.

Grevsen, K., and J.N. Sorensen. 2004. Sprouting and yield in bulb onions (Allium cepa L.) as influenced by cultivar, plant establishment methods, maturity at harvest and storage conditions. Journal of Horticultural Science and Biotechnology 79:877-884.

Havey, M.J. 2000. Alliums breeding and genetics during the $20^{\text {th }}$ and $21^{\text {th }}$ Centuries. p. 16-21. Proceedings of the Third International Symposium on Edible Alliaceae, Athens, Georgia, USA. 30 October-3 November 2000. University of Georgia, Athens, Georgia, USA.

IRRI. 2003. IRRISTAT 4.0 Windows. International Rice Research Institute (IRRI). Biometrics Unit. Available at http://www.irristat. software.informer.com (accessed March 2011).

Khokhar, K.M. 2008. Effect of temperature and photoperiod on the incidence of bulbing and bolting in seedlings of onion cultivars of diverse origin. Journal of Horticultural Science and Biotechnology 83:488-496.

McCallum, J.A., D.G. Grant, E.P. McCartney, J. Scheffer, M.L. Shaw, and R.C. Butler. 2001. Genotypic and environmental variation in bulb composition of New Zealand adapted onion (Allium cepa) germplasm. New Zealand Journal of Crop and Horticultural Science 29:149-158.

Muro, T., K. Ito, Y. Sato, H. Abe, H. Turui, H. Asari, Y. Minagawa, and H. Harada. 2006. Breeding of early-maturing hybrid onion variety 'Early Globe' and its characteristics. Research Bulletin of the National Agricultural Research Center for Hokkaido Region 184:45-55.

Shock, C.C., E. Feibert, and L.D. Saunders. 2005. Singlecentered and super colossal bulbs from yellow onion cultivars. HortTechnology 15:399-408. 